\title{
Hydrodynamic and Soil Biodiversity Characterization in an Active Landslide
}

\author{
Sara Remelli, Emma Petrella $\mathbb{D}^{D}$, Alessandro Chelli, Federica Delia Conti, Carlos Lozano Fondón $\mathbb{D}$, \\ Fulvio Celico ${ }^{\mathbb{D}}$, Roberto Francese and Cristina Menta *
}

Department of Chemistry, Life Sciences and Environmental Sustainability, University of Parma, Viale delle Scienze 11/A, 43124 Parma, Italy; sara.remelli@unipr.it (S.R.); emma.petrella@unipr.it (E.P.); alessandro.chelli@unipr.it (A.C.); conti.federica@gmail.com (F.D.C.); lzncls@unife.it (C.L.F.); fulvio.celico@unipr.it (F.C.); roberto.francese@unipr.it (R.F.)

* Correspondence: cristina.menta@unipr.it

Received: 10 July 2019; Accepted: 6 September 2019; Published: 10 September 2019

\begin{abstract}
Landslides are common in the Northern Apennines (Italy) and their resulting changes in soil structure affect edaphic fauna biodiversity, whose activity has concurrent impacts on soil structural stability and water-holding capacity. The aim of this study was to characterise landslide evolution and assess potential relationships between its hydrogeological features and soil fauna. The landforms of the study area, located in the River Taro valley, were mapped and the hydraulic head fluctuations and groundwater electrical conductivity profiles were measured. The soil arthropod community was studied in seven sites, one subject to earth flow and six to rotational slide; the last ones were divided into the main scarp of the slide, and five sites characterized by different land use: three grassland, a wheat cultivated field and an overgrown area. Soil organic matter (SOM) and $\mathrm{pH}$ measurements were performed. Hydrogeological results suggest unexpected rapid percolation of relatively low-salinity waters through the unsaturated zone. Both lower SOM content and arthropod biodiversity were found in earth flow area, while higher values were found in grasslands. Fauna composition appears to be a good indicator of soil degradation processes, linked to the hydraulic features, and contributes to the evaluation of the soil condition in landslide areas for further agricultural purposes.
\end{abstract}

Keywords: microarthropods; soil fauna; low-permeability media; porosity; soil organic matter; Collembola; hydraulic features; aquifer heterogeneity

\section{Introduction}

Landslides are complex systems dependent on geological, geomorphological, hydrogeological and geotechnical factors, and represent worldwide danger for people, buildings and transportation infrastructures. They are common in the Northern Apennines (Italy), a folded and thrusted belt developed since the Cretaceous period [1-4], where different types of landslides can be detected and large earth flows are widespread [5]. In several areas, earth or rock rotational and/or translational slides evolve into earth flows [6,7]. These landslides can be huge [8], and the affected areas can reach up to $10^{5} \mathrm{~m}^{2}$ (with displaced volumes up to $10^{8} \mathrm{~m}^{3}$ ).

A major role is played by tectonics, which caused the development of faults and thrusts (representing weak zones with associated sets of fractures) controlling the recent uplift that conditioned most of the slopes' geomorphological evolution [6,9]. Nevertheless, rainfall is the triggering factor, especially during those seasons (usually, autumn and spring) that are characterised by precipitations lasting for several days [10]. The distribution of precipitation is influenced by the recent climate changes [11], and prolonged dry periods alternated with intense rainfalls are more and more frequent. The relationship between initial slope conditions and rainfall frequency/intensity, and the reactivation 
of large landslides is a major research challenge [12,13], and some authors have attempted to find one-to-one correlation between rainfalls thresholds and slope failures [14], or to integrate methods [15].

Above- and belowground biodiversity is affected by landslides: changes in site condition lead to changes in soil physical and chemical composition and, consequently, in vegetation cover, contributing to increased habitat diversity [16]. The most obvious consequences of landslides are on topography, yet these processes also have a substantial impact on soil properties, by exposing parent material and removing organic matter and A horizons that lead to textural and chemical changes. Landslide processes often bear textural sorting; moreover, remoulding and liquefaction of clays and silts in earth flows reduce structure and porosity, and increase soil density [17]. Changes in soil density and porosity are consequences of erosion, which leads to changes in soil chemistry too [17]. Soil organic matter is mostly found in the soil surface, therefore decreases significantly through erosion; formation of soil aggregates is consequently disrupted, and soil porosity decreases. Reduced soil organic matter leads to overall diminishing of biomass and productivity [18] and sets back the ecosystem to the initial stages of soil development, with deep un-weathered parent material and rock exposure. Since soil biota is affected by the amount of organic matter, its reduction affects biodiversity [19]. Moreover, changes in topography and soil properties and the resultant changes in vegetation, shape a gap between landslides and the surrounding habitat, with chance of settlement for different soil communities. Age and position on the landslide also influence habitat and vegetation communities, as demonstrated by Smith et al. [20] when studying revegetation patterns on debris slides and flows. Changes in fauna community also occur because earth flows create ponds that predispose sites to beaver colonization and floristic explosions on landslide deposits support deciduous-dependent fauna, while soil cliffs related to rotational landslides provide a habitat for small mammals [16]. Since a landslide can be considered a disturbance agent that changes soil and vegetation patterns, changes in edaphic fauna are also expected because soil fauna is closely linked to soil properties and vegetation.

The aim of this research was: (i) to study the effects of a landslide complex on soil biodiversity, in terms of soil arthropod community, in different areas involved in the landslide process (agriculture ecosystems, abandoned farmlands, etc.), and (ii) connect geohydrological information with soil biodiversity in order to show how soil fauna can be used in landslide studies.

\section{Materials and Methods}

\subsection{Study Area}

The study area (Case Pennetta landslide) is located in the Taro River valley (Northern Apennines). During the past 25 years, the local climate condition has been characterized by annual mean precipitation ranging from 938 to $1230 \mathrm{~mm}$, and annual mean temperature between $11.0-12.4^{\circ} \mathrm{C}$ [10].

In the area, three tectonic units belonging to the Ligurian Domain of the Northern Apennines [21] outcrop. In detail, the geological sequence can be described as follows (from the top to the bottom of the slope): (i) Arenarie di Scabiazza (SCB), made up of thin layers of claystone alternating with sandstone layers, 15 to $20 \mathrm{~cm}$ thick, that gradually change from thin to very thin sandstone layers ending with marls; (ii) Argille a Palombini di Monte Rizzone (AMR), made up of claystones and intercalated decimetric limestone beds. Locally, AMR disappears and SCB lies directly on the rocks of the underlying Ottone tectonic unit, which is made of claystones containing clasts and blocks of limestone (Argille a blocchi, $\mathrm{CCVb}$ ); (iii) these lie directly (tectonic boundary) on the underlying Flysch of Monte Caio (CAO), which is made up of thick beds of marly-limestones turbidites and intercalated thin-to-medium argillite beds. All the rocks are deeply tectonised and the layering is locally completely destroyed.

Steep surfaces and scarps usually characterize the lower portion of the studied slope, where the thick beds of marly-limestones turbidites (CAO) crop out. Conversely, milder and smooth landforms are usually found in the upper portion, due to prevailing rocks containing clay and claystone (AMR, CCVb), with the exclusion of the areas affected by landslides. 
The main known reactivations of the Case Pennetta landslide occurred in 1916, 1927 and 2000-2001. During this last event, a state road and the Parma-La Spezia railway were involved in the mass movement. Moreover, new surficial effects of the slope's instability have been detected since 2010, both in the fields (cracks and changes in slope shape and dip), and on structures and houses (tilting and microcracks). The landslide's rate of movement was usually in the order of a few mm/year to a few $\mathrm{cm} /$ year (from extremely slow to very slow in the velocity scale by Cruden and Varnes [22]), even though some acceleration was observed during total reactivation events (e.g., in 1927 and in 2001). In the past, the landslide underwent a limited number of interventions, essentially in underground and surficial drainage systems.

\subsection{Geological and Geomorphological Survey}

The landforms were mapped by merging geomorphological maps and different datasets [23]. A digital surface model (DSM) of the study site was constructed via photogrammetric mapping using an unmanned aerial vehicle (UAV). DSM was later converted onto a digital terrain model (DTM) voiding vegetation with terrain contours from available digital cartography. Differential GPS measurements provided ground control points for UAV images and also benchmarks for areas covered by vegetation. Elevation contour lines, available from Regional Technical Cartography at scale 1:5000 [23] were utilized to fill in data gaps. The different data types were finally interpolated on a $1 \mathrm{~m}$ aperture mesh using a kriging algorithm.

Investigations were performed to acquire the subsurface geological features. Two corings (SI1 and SI2) were drilled within the study site at different depths beneath the field surface (Figure 1a).

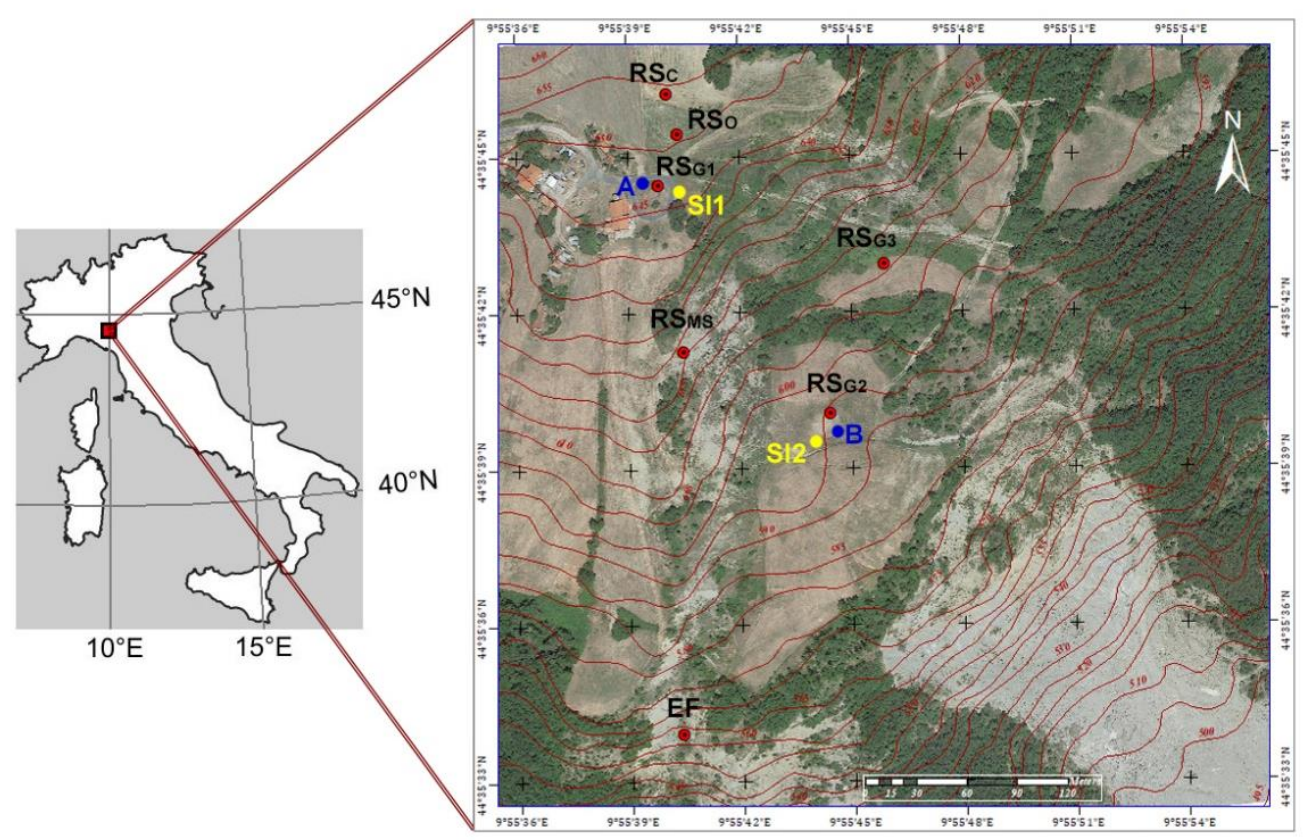

(a)

Figure 1. Cont. 


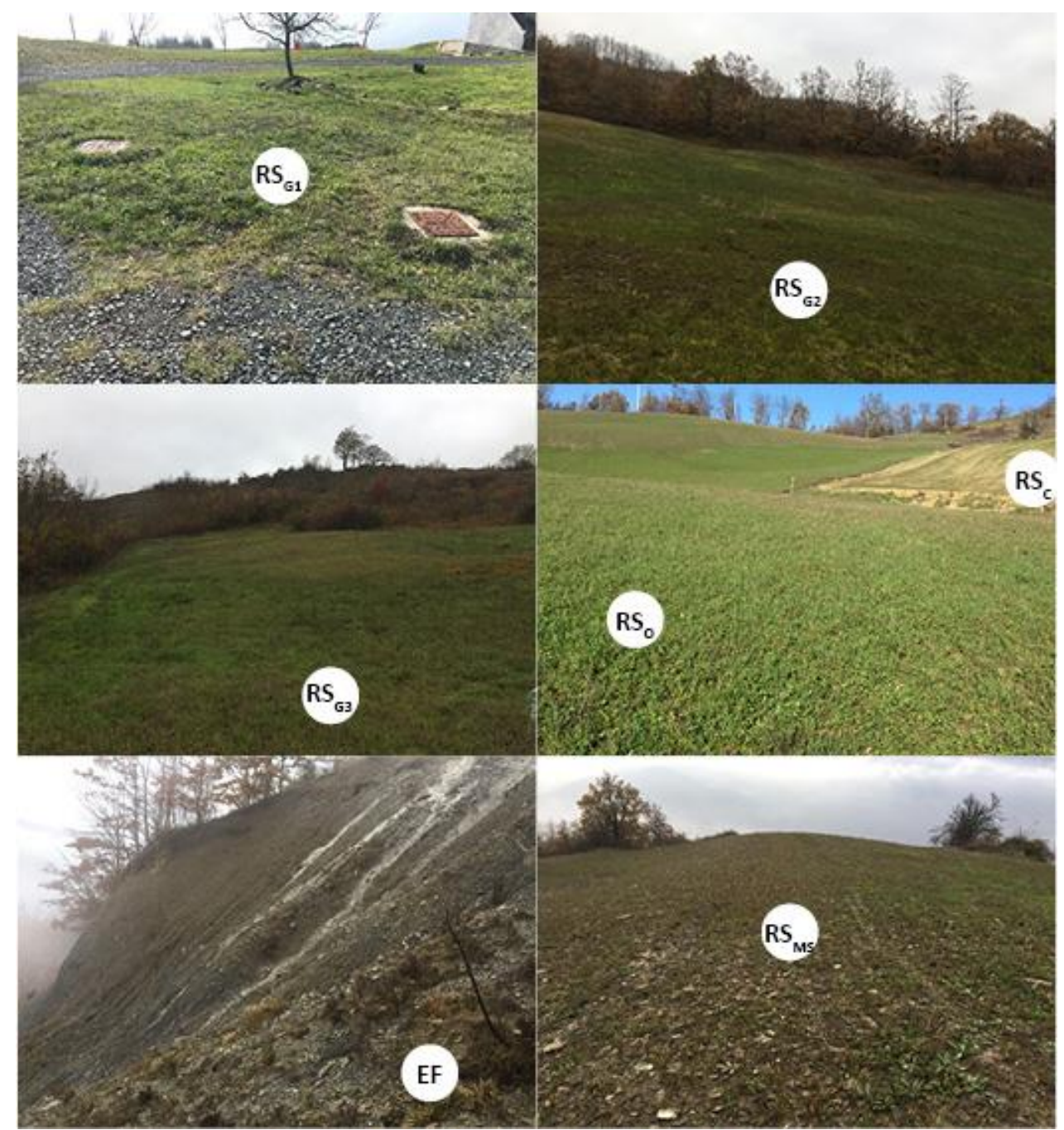

(b)

Figure 1. (a) Location of the piezometers (blue points), the corings (yellow points) and the soil sampling sites (red points) (the contour lines show the altitude in meters above sea level); (b) Sampling sites: $\mathrm{RS}_{\mathrm{G} 1}$ : Rotational Slide-Grassland 1; $\mathrm{RS}_{\mathrm{G} 2}$ : Rotational Slide-Grassland 2; $\mathrm{RS}_{\mathrm{G} 3}$ : Rotational Slide-Grassland 3; $\mathrm{RS}_{\mathrm{O}}$ : Rotational Slide-Overgrown; $\mathrm{RS}_{\mathrm{C}}$ : and Rotational Slide-Cultivated; EF: Earth Flow; $\mathrm{RS}_{\mathrm{MS}}$ : Rotational Slide-Main Scarp.

\subsection{Hydrogeological Investigations}

Two piezometers were drilled to measure the hydraulic head fluctuations and the groundwater electrical conductivity (EC) profiles within the investigated groundwater (Figure 1a). Piezometer A is $25-\mathrm{m}$ deep and screened between 1 and $25 \mathrm{~m}$ below ground (623 to $648 \mathrm{~m}$ a.s.1.). Piezometer B is $15 \mathrm{~m}$ deep and screened between 3 and $15 \mathrm{~m}$ below ground (576 to $588 \mathrm{~m}$ a.s.l.). Both piezometers were drilled very close to the cores SI1 and SI2 (Figure 1a).

In each of the two piezometers, a pressure transducer with data-logger (STS DL.OCS/N/RS485) was installed to monitor the hydraulic head on an hourly basis, from May 2017 to May 2018. The same piezometers were used to measure the hydraulic head through a water level meter, on a monthly basis from April 2017 onwards.

The EC of groundwater was measured inside the screened interval of each piezometer, in order to analyse possible haloclines and use the groundwater EC to investigate the hydrogeological behaviour of the studied system, according to previous studies [24-27]. EC vertical profiles were measured on a monthly basis with a borehole probe (SOLINST TLC), from April 2017 to May 2018. Measurements 
were carried out at 1-m-depth intervals. The effectiveness of EC values was always verified through laboratory analyses.

\subsection{Soil Samples and Chemical Analysis}

Soil samples were collected in seven sites located in the study area: six of those were taken from the area affected by the rotational slide and one from the earth flow (Table 1; Figure 1a,b). The sites were selected within the rotational slide to analyse differences (i) among the land use types (cultivated, overgrown, grassland) observed at the study area, and (ii) between the main scarp and the flat areas.

Table 1. Sampling sites characteristics.

\begin{tabular}{|c|c|c|c|}
\hline Site Code & Movement Type & Land Use & Coordinates (UTM) \\
\hline EF & Earth flow & Eroded zone belonging to the active earth flow area & 32N 5736454938131 \\
\hline $\mathrm{RS}_{\mathrm{C}}$ & Rotational slide & Wheat cultivated field & 32N 5736344938510 \\
\hline $\mathrm{RS}_{\mathrm{G} 1}$ & Rotational slide & Permanent grassland & $32 N 5736284938442$ \\
\hline $\mathrm{RS}_{\mathrm{G} 2}$ & Rotational slide & Permanent grassland & 32N 5737324938321 \\
\hline $\mathrm{RS}_{\mathrm{G} 3}$ & Rotational slide & Permanent grassland & 32N 5737644938410 \\
\hline $\mathrm{RS}_{\mathrm{MS}}$ & Rotational slide & Main scarp with scarce vegetation cover & 32N 5736454938357 \\
\hline $\mathrm{RS}_{\mathrm{O}}$ & Rotational slide & Overgrown field & 32N 5736414938486 \\
\hline
\end{tabular}

Soil samples were collected for chemical analysis according to FAO recommendations [28]. Nine soil subsamples were used to perform $\mathrm{pH}$ and soil organic matter (SOM) analyses. $\mathrm{pH}$ analysis was conducted by placing a $\mathrm{pH}$ meter in a soil:distilled water liquid mixture in ratio 1:2.5 [29]; SOM was determined by using LOI-Loss on Ignition according to Ball's method [30], and igniting $1 \mathrm{~g}$ of dried soil at $450{ }^{\circ} \mathrm{C}$ for $4 \mathrm{~h}$.

\subsection{Soil Arthropod Investigation}

Three soil samples $\left(10 \times 10 \times 10 \mathrm{~cm}^{3}\right)$ were collected from each site in November 2018 for soil microarthropod extraction. Arthropod extraction was performed via the Berlese-Tüllgren funnel ( $2 \mathrm{~mm}$ sieve mesh; extraction time 10 days), and the specimens were placed in a preservative solution (75\% ethyl alcohol and 25\% glycerol by volume). Class taxonomic level for Myriapoda, and order level for Hexapoda, Chelicerata and Crustacea [31] were considered. Collembola and Acari are generally the two most present groups, in terms of species diversity and abundance, so these two groups were studied more in-depth. Collembola were classified at family level, and Acari were divided between Oribatida and other Acari. The number of specimens present for each group was counted and their abundance (ind $/ \mathrm{m}^{2}$ ) registered. Number of taxa (NT) and Acari-to-Collembola ratio (A/C) [32] were calculated on the basis of this classification level.

\subsection{Statistical Analysis}

The Pearson correlation coefficient was used to determine if there was a relation between $\mathrm{pH}$ and SOM. The Kruskal-Wallis test for multiple comparison was performed to establish if the study sites differed in $\mathrm{pH}$ and SOM. Where significance was found $(p \leq 0.05)$, pairwise multiple comparisons between sites according to Conover were made as post-hoc.

Total abundance, number of taxa as well as abundance of taxa always present in the study sites and Acari/Collembola ratio were compared by using the Conover test as done for environmental parameters. The Akaike's Information Criterion (AIC) was used to establish the best model to study soil fauna community data matrix. The R package "vegan" was used for arthropod communities to observe variance in community composition depending on the study site and its environmental characteristics. The Bray-Curtis distance was calculated as a measure of the dissimilarity between sites in the composition of the edaphic community, considering both the presence and the abundance of the different groups found; true abundances were log-transformed according to Borcard [33], in order to 
avoid placing the same importance on absolute differences in abundance without considering their order of magnitude. The same tests performed to study total community composition were conducted for Collembola communities. All data were analysed using R version 3.5.2 (R Core Team, Vienna, Austria) [34].

\section{Results}

\subsection{Geological and Geomorphological Features of the Landslide}

The Case Pennetta landslide extends from $650 \mathrm{~m}$ a.s.l. to the Taro riverbed ( $265 \mathrm{~m}$ a.s.l.). Its length is about $1600 \mathrm{~m}$, and its maximum width is approximately $130 \mathrm{~m}$. The geomorphological map (Figure 2) shows the landslide's main landforms, with emphasis on the portions analysed within this study (rotational slide and upper part of the earth flow). The well-developed main scarp, characterised by a concave longitudinal topographic profile, and the head surface (in the counter-slope) account for a typical rotational movement.

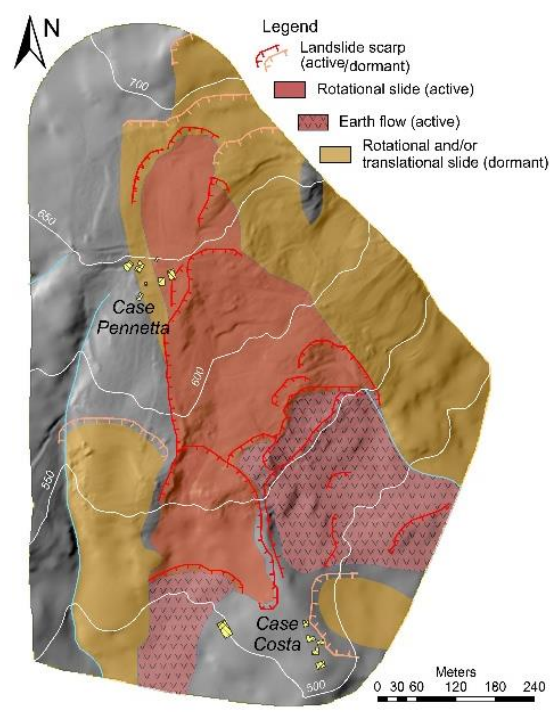

Figure 2. Geomorphological map. The contour lines show the altitude in meters above sea level.

This kinematic type pertains to the depleted mass of the landslide that extends down to $510 \mathrm{~m}$ a.s.l., where the toe of the failure surface is masked by the materials accumulated. Earth flows start from the front of this depleted mass and reach the Taro River, representing the foot of the landslide.

The rotational part of the landslide affects SCB and marginally AMR. Core SI1 (Figure 1a) shows, down to 30-31 m below ground (b.g.; 616-615 $\mathrm{m}$ a.s.1.), a matrix supported deposit characterized by a clay-silty matrix, clasts of different size $(0.5$ to $12 \mathrm{~cm})$. From $31 \mathrm{~m}$ to $34 \mathrm{~m} \mathrm{~b}$.g. the deposit is clast-supported and poorer in matrix compared to the upper portion. The top of the bedrock was detected at $35 \mathrm{~m}$ b.g. ( $612 \mathrm{~m}$ a.s.l.). Between 6-9 $\mathrm{m}$ and 11-14 $\mathrm{m}$ b.g., there is an alternation of compact and loose levels with a certain degree of disaggregation. Between $21 \mathrm{~m}$ and $23 \mathrm{~m} \mathrm{~b}$.g., the rocks are more disaggregated. Core SI2 (Figure 1a) shows clasts and blocks of different size (from grains to $12 \mathrm{~cm}$ ) with abundant silty-clay matrix, from the ground surface to $20 \mathrm{~m}$ b.g. A level richer in clay was observed at 14-15 m b.g. Dispersed organic material has also been found in the first $20 \mathrm{~m}$ of coring. Between 20 and $23 \mathrm{~m} \mathrm{~b}$.g., the deposit is clast-supported, with clasts up to $10 \mathrm{~cm}$ in size. Between 21 and $21.50 \mathrm{~m} \mathrm{b.g}$. the matrix is more abundant than in the other portion of this depth interval. At $23 \mathrm{~m} \mathrm{b.g}$. (561 m a.s.l.), the rock is made of thin layers of claystone and sandstones (SCB). 


\subsection{Hydrogeological Behaviour}

Hydraulic head measurements show several peaks during infiltration events (Figure 3), therefore suggesting rapid percolation of water from the ground surface towards the saturated zone. The groundwater EC varies significantly with depth, and the haloclines show variations over time, strictly related to local precipitations (see examples in Figure 3). Therefore, according to the results obtained in other sites [26,35], these EC variations depend on the effective infiltration of local rainwater that determines the mixing between lower-salinity fresh infiltration waters and higher-salinity pre-event groundwater. In both piezometers A and B, the EC in groundwater varies significantly with depth (Figure 3), with a great difference between the bottom (e.g., $>4000 \mu \mathrm{S} / \mathrm{cm}$ in piezometer A) and the top value (e.g., around $1000 \mu \mathrm{S} / \mathrm{cm}$ in piezometer A). A step-like shape is observed in both wells. In each of the wells, the EC steps were always detected at the same depth.

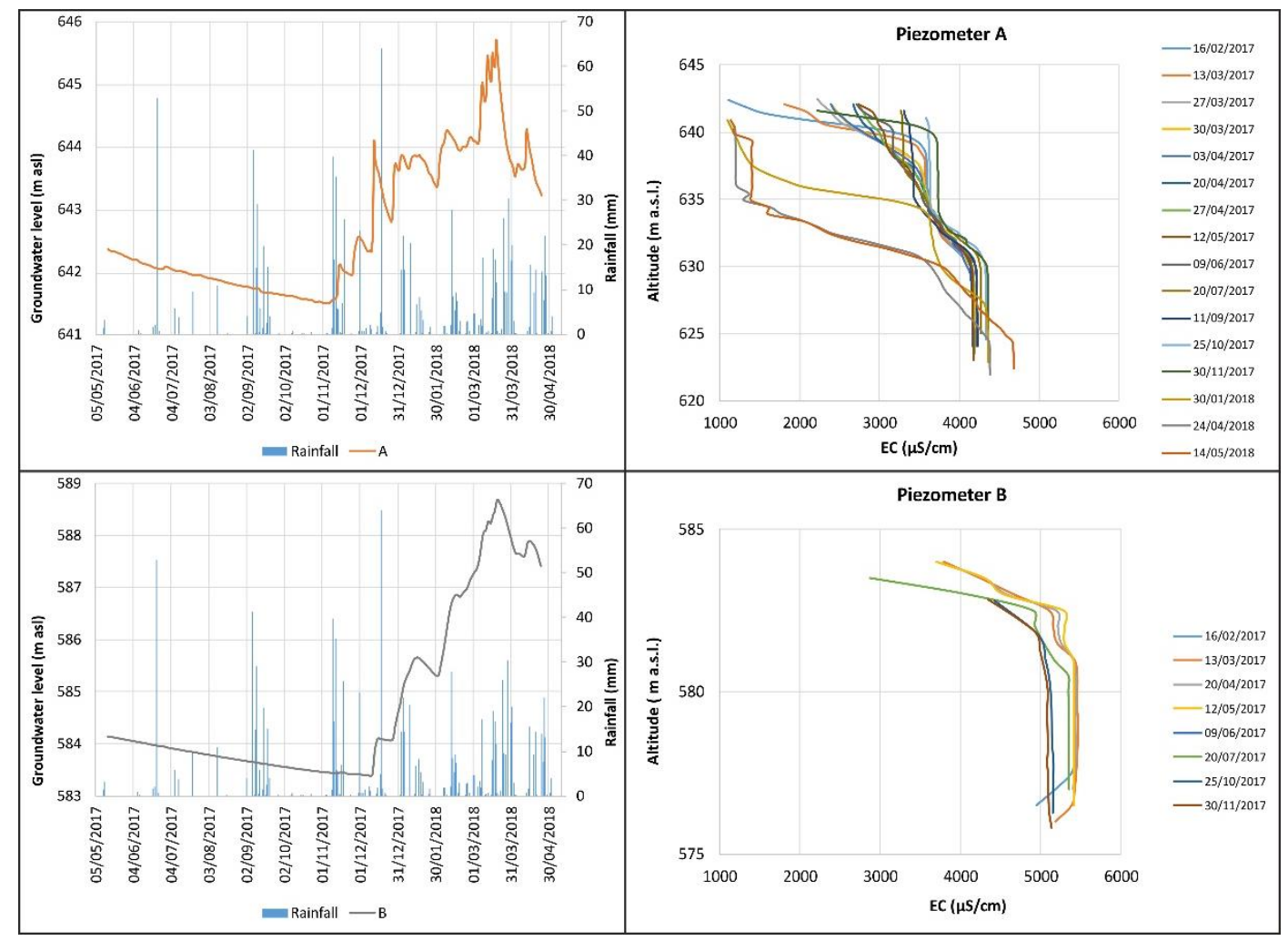

Figure 3. Hydraulic head fluctuations measured in piezometers A and B, and daily precipitation recorded at Mormorola station and the vertical profile of electrical conductivity (EC) in piezometers A and B.

On the whole, the hydrogeological investigations depict (i) a near-surface medium that is characterised by both porosity and permeability higher than those expected in clay-rich sediments (see rapid effective infiltration and arrival of fresh-infiltration waters at the groundwater table), and (ii) relatively low salinity of waters percolating through the unsaturated zone.

\subsection{Soil Characterization}

Results of $\mathrm{pH}$ and SOM are shown in Figure 4. The different $\mathrm{pH}$ values, from neutral to moderately alkaline, were not significantly distinct from each other, while percentages of SOM depended on the sampling sites $(p<0.05)$. In the $\mathrm{RS}_{\mathrm{G} 1}, \mathrm{SOM}$ appeared to be higher than in the $\mathrm{RS}_{\mathrm{C}}, \operatorname{RS}_{\mathrm{MS}}(p<0.05)$ and $\mathrm{EF}$ areas $(p<0.01)$, in which it was significantly lower than in $\mathrm{RS}_{\mathrm{G} 2}$ and $\mathrm{RS}_{\mathrm{G} 3}(p \leq 0.05 ; p<0.01)$. According to the Pearson correlation, there was no relation between SOM and $\mathrm{pH}$ found in this study area. 


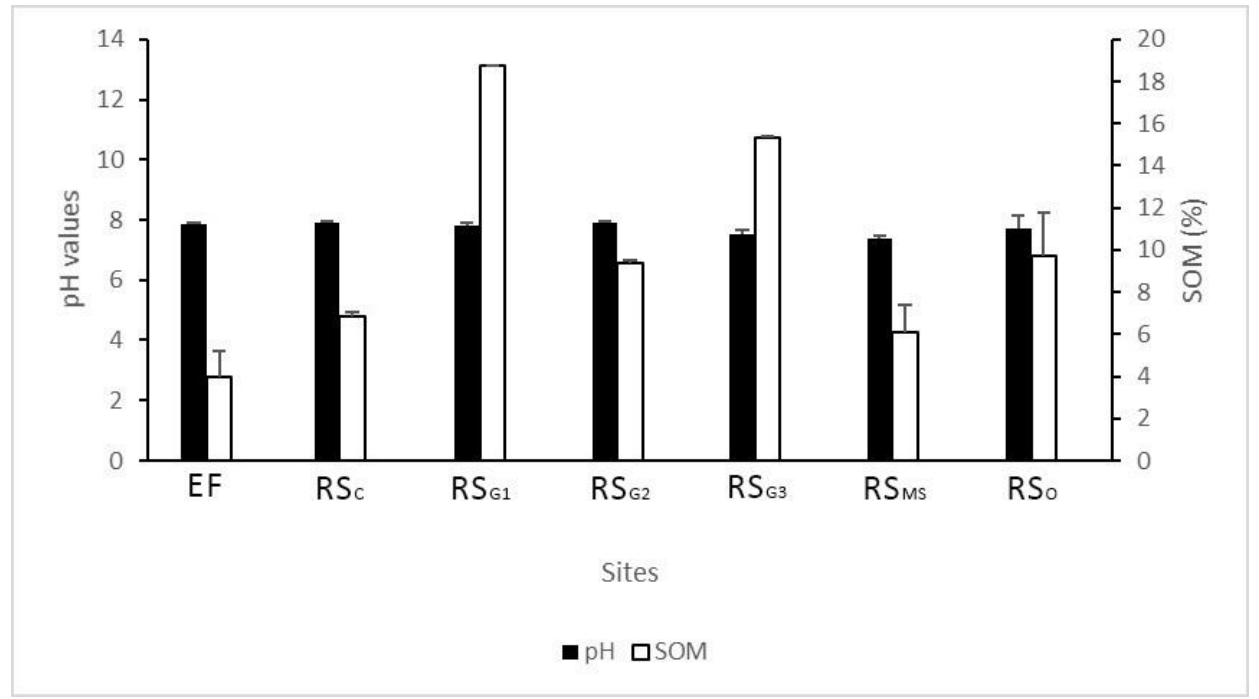

Figure 4. Average and standard error of the $\mathrm{pH}$ and SOM found in each site.

\subsection{Soil Microarthropod Community}

Table 2 shows the results of soil microarthropod community. Overall, 17 taxa were found in the study area, five of which found in all sites: Acari, Coleoptera, Collembola, Diptera and Hemiptera. The greatest total abundance per $\mathrm{m}^{2}$ was found in $\mathrm{RS}_{\mathrm{G} 2}$, statistically higher than $\mathrm{RS}_{\mathrm{C}}$, $\mathrm{RS}_{\mathrm{MS}}, \mathrm{RS}_{\mathrm{G} 3}(p \leq 0.05)$ and $\mathrm{EF}(p<0.01)$; EF showed the lowest abundance, less than in $\mathrm{RS}_{\mathrm{O}}$ and $\mathrm{RS}_{\mathrm{G} 1}(p<0.05) . \mathrm{RS}_{\mathrm{C}}$ and $\mathrm{EF}$ areas revealed a significantly lower number of groups than the other sites $(p \leq 0.05)$, except for the comparison between $\mathrm{RS}_{\mathrm{C}}$ and $\mathrm{RS}_{\mathrm{G}} 1$, and between both $\mathrm{RS}_{\mathrm{C}}$ and EF, and $\mathrm{RS}_{\mathrm{MS}}$. The best model to study soil fauna community data matrix was considering site and SOM as independent variables, with the result that each one contributed significantly to edaphic community composition ( $p<0.01$ and $p \leq 0.05$ respectively). The Bray-Curtis distance denoted the greatest dissimilarity (from $38 \%$ to $50 \%$ ) between $\mathrm{EF}$ and the other sites, particularly $\mathrm{RS}_{\mathrm{G} 2}$, while fauna composition appeared to be similar for over $80 \%$ between $\mathrm{RS}_{\mathrm{G} 2}, \mathrm{RS}_{\mathrm{G} 3}$ and $\mathrm{RS}_{\mathrm{O}}$ (Figure 5).

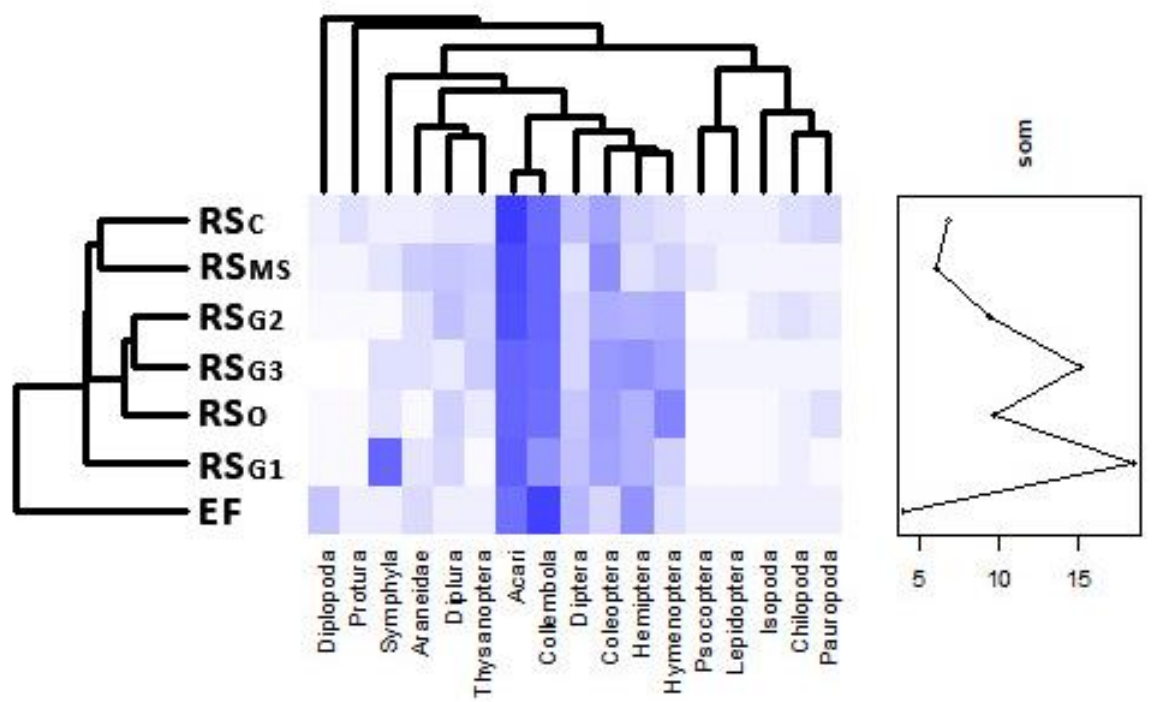

Figure 5. Heat map of the community composition, with colour intensities proportional to taxa abundance, and UPGMA (unweighted pair-group method using arithmetic averages) clustering of a matrix of Bray-Curtis distance among sites (on the left side) and of the taxa that occur more often together (on the top side); on the right side, the SOM values are displayed. 
Table 2. Average \pm standard error of the number of individuals (ind. $/ \mathrm{m}^{2}$ ) for each faunal group, the number of groups, the total abundance (ind. $/ \mathrm{m}^{2}$ ) and the ratio Acari/Collembola found in the seven sites studied.

\begin{tabular}{|c|c|c|c|c|c|c|c|}
\hline Faunal Group & EF & $\mathbf{R S}_{\mathrm{c}}$ & $\mathrm{RS}_{\mathrm{G} 1}$ & $\mathrm{RS}_{\mathrm{G} 2}$ & $\mathrm{RS}_{\mathrm{G} 3}$ & $\mathbf{R S}_{\mathrm{MS}}$ & $\mathrm{RS}_{\mathrm{O}}$ \\
\hline Acari & $311 \pm 79$ & $7268 \pm 5867$ & $7844 \pm 447$ & $27,588 \pm 2654$ & $4681 \pm 313$ & $6008 \pm 3273$ & $4897 \pm 1345$ \\
\hline Araneidae & $14 \pm 7$ & & $21 \pm 0$ & $42 \pm 12$ & $42 \pm 12$ & $64 \pm 37$ & - \\
\hline Chilopoda & - & $14 \pm 7$ & $11 \pm 6$ & $42 \pm 25$ & $11 \pm 6$ & - & $7 \pm 7$ \\
\hline Coleoptera & $14 \pm 7$ & $255 \pm 131$ & $573 \pm 123$ & $499 \pm 67$ & $796 \pm 190$ & $594 \pm 294$ & $566 \pm 209$ \\
\hline Larvae & - & $255 \pm 161$ & $541 \pm 244$ & $403 \pm 74$ & $786 \pm 196$ & $531 \pm 305$ & $559 \pm 203$ \\
\hline Collembola & $870 \pm 492$ & $1755 \pm 494$ & $1040 \pm 123$ & $10,870 \pm 650$ & $3917 \pm 1122$ & $2420 \pm 735$ & $3276 \pm 1769$ \\
\hline Diplopoda & $28 \pm 19$ & - & - & - & - & - & - \\
\hline Diplura & - & $7 \pm 7$ & $53 \pm 18$ & $202 \pm 80$ & $21 \pm 12$ & $74 \pm 18$ & $64 \pm 25$ \\
\hline Diptera & $50 \pm 7$ & $78 \pm 58$ & $159 \pm 43$ & $74 \pm 18$ & $74 \pm 6$ & $21 \pm 7$ & $120 \pm 57$ \\
\hline Larvae & $14 \pm 7$ & $64 \pm 44$ & $42 \pm 21$ & $64 \pm 25$ & $11 \pm 6$ & $11 \pm 7$ & $64 \pm 12$ \\
\hline Hemiptera & $142 \pm 131$ & $28 \pm 14$ & $276 \pm 86$ & $393 \pm 153$ & $902 \pm 337$ & $21 \pm 12$ & $248 \pm 146$ \\
\hline Hymenoptera & $7 \pm 7$ & - & $85 \pm 37$ & $510 \pm 270$ & $510 \pm 221$ & $42 \pm 25$ & $1720 \pm 1481$ \\
\hline Isopoda & - & - & - & $21 \pm 12$ & $11 \pm 6$ & - & - \\
\hline Lepidoptera & - & - & - & - & $11 \pm 6$ & - & - \\
\hline Larvae & - & - & - & - & $11 \pm 6$ & - & - \\
\hline Pauropoda & - & $28 \pm 19$ & - & $21 \pm 12$ & $11 \pm 6$ & - & $28 \pm 14$ \\
\hline Protura & - & $14 \pm 14$ & - & - & - & - & - \\
\hline Psocoptera & - & - & - & - & $11 \pm 6$ & $11 \pm 6$ & - \\
\hline Symphyla & - & - & $6496 \pm 2415$ & - & $42 \pm 12$ & $11 \pm 6$ & $21 \pm 12$ \\
\hline Thysanoptera & - & $7 \pm 7$ & - & $117 \pm 6$ & $106 \pm 61$ & $53 \pm 31$ & $14 \pm 7$ \\
\hline Number of groups & $8 \pm 1$ & $10 \pm 0$ & $10 \pm 0$ & $11 \pm 1$ & $13 \pm 1$ & $10 \pm 1$ & $10 \pm 0$ \\
\hline Total abundance & $1437 \pm 709$ & $9469 \pm 5699$ & $16,559 \pm 2674$ & $40,379 \pm 3711$ & $11,146 \pm 1243$ & $9320 \pm 4380$ & $10,962 \pm 3910$ \\
\hline Acari/Collembola & $2 \pm 1$ & $6 \pm 5$ & $8 \pm 1$ & $3 \pm 0$ & $1 \pm 0$ & $2 \pm 1$ & $2 \pm 1$ \\
\hline
\end{tabular}

Greater Acari abundance was found in $\mathrm{RS}_{\mathrm{G} 2}$, significantly higher than in $\operatorname{RS}_{\mathrm{C}}(p<0.05)$ and EF sites $(p<0.01)$; in $\mathrm{EF}$ their presence was lower than $\mathrm{RS}_{\mathrm{O}}$ and $\mathrm{RS}_{\mathrm{G} 1}(p<0.05)$. Among them, a distinction was made between those belonging to Oribatida and to other Acari (Figure 6). The Acari community strongly depends on the site $(p \leq 0.01)$; with EF abundance of Oribatida significantly lower than that of the other sites $(p<0.05)$ except for $\mathrm{RS}_{\mathrm{C}}$ (lower than $\left.\mathrm{RS}_{\mathrm{G} 2}, p<0.05\right)$ and $\mathrm{RS}_{\mathrm{MS}}$. The abundance of Oribatida was greater than other Acari in $\mathrm{RS}_{\mathrm{G} 3}$ and $\mathrm{RS}_{\mathrm{O}}$ only.

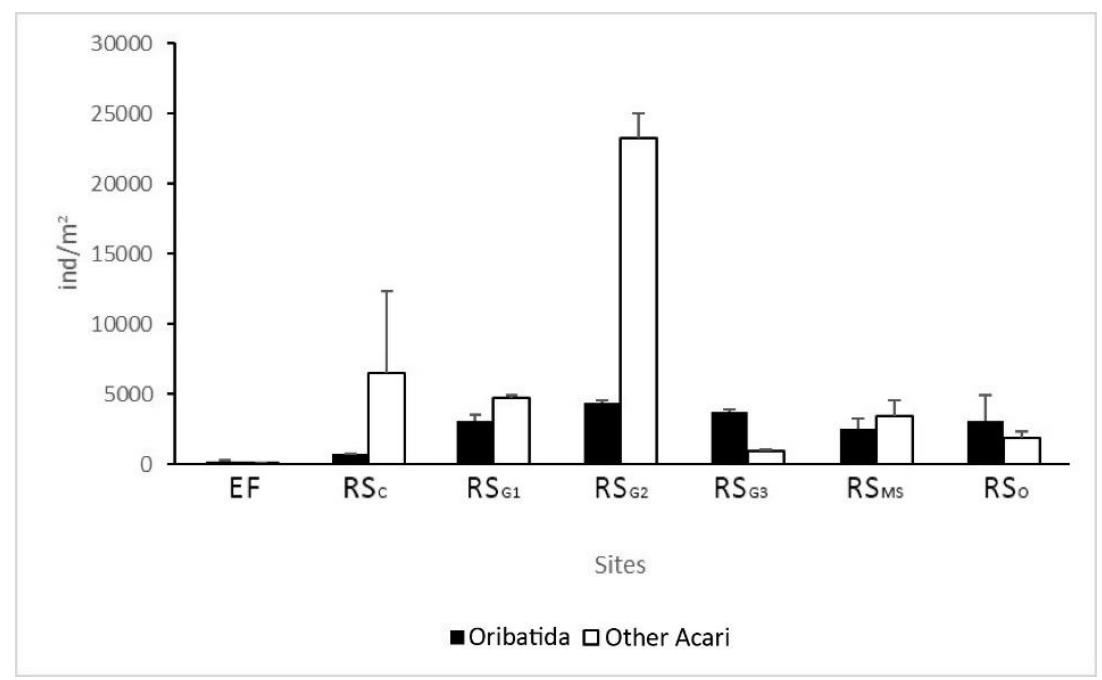

Figure 6. Average and standard error of the number of Oribatida and others Acari (ind. $/ \mathrm{m}^{2}$ ) found in each site.

Like Acari, less abundant Coleoptera and Collembola were found in EF. The number of Coleoptera in $\mathrm{EF}$ was lower than in $\mathrm{RS}_{\mathrm{G} 3}$ and in $\mathrm{RS}_{\mathrm{O}}(p<0.05)$. The abundance of Collembola observed in $\mathrm{RS}_{\mathrm{G} 2}$ was statistically greater than in $\mathrm{RS}_{\mathrm{G} 1}$ and in $\mathrm{EF}(p<0.05, p<0.01)$. Ten Collembola families were identified (Table 3), with four present in all sites: Entomobryidae, Hypogastruridae, Isotomidae and Onychiuridae/Tullbergiidae. 
Table 3. Average \pm standard error of the number of Collembola per $\mathrm{m}^{2}$.

\begin{tabular}{cccccccc}
\hline Collembola Family & $\mathbf{E F}$ & $\mathbf{R S}_{\mathbf{C}}$ & $\mathbf{R S}_{\mathbf{G} 1}$ & $\mathbf{R S}_{\mathbf{G} 2}$ & $\mathbf{R S}_{\mathbf{G} 3}$ & $\mathbf{R S}_{\mathbf{M S}}$ & $\mathbf{R S}_{\mathbf{O}}$ \\
\hline Arrhopalitidae & - & $7 \pm 7$ & - & $11 \pm 6$ & - & - & - \\
Entomobryidae & $623 \pm 429$ & $934 \pm 532$ & $563 \pm 67$ & $393 \pm 80$ & $955 \pm 110$ & $1306 \pm 215$ & $205 \pm 51$ \\
Hypogastruridae & $71 \pm 51$ & $14 \pm 7$ & $21 \pm 12$ & $138 \pm 18$ & $1337 \pm 735$ & $106 \pm 61$ & $1076 \pm 416$ \\
Isotomidae & $85 \pm 65$ & $425 \pm 170$ & $96 \pm 31$ & $10,243 \pm 766$ & $329 \pm 116$ & $616 \pm 282$ & $1592 \pm 1392$ \\
Neanuridae & $21 \pm 12$ & $7 \pm 7$ & - & - & - & - & - \\
Onychiuridae/Tullbergiidae & $64 \pm 64$ & $361 \pm 165$ & $350 \pm 67$ & $42 \pm 12$ & $1136 \pm 313$ & $265 \pm 104$ & $255 \pm 44$ \\
Odontellidae & - & - & - & $11 \pm 6$ & - & - & - \\
Katiannidae & - & $7 \pm 7$ & - & - & - & - & $42 \pm 21$ \\
Sminthuridae & - & - & $11 \pm 6$ & $32 \pm 6$ & $117 \pm 55$ & $127 \pm 74$ & $21 \pm 12$ \\
Sminthurididae & $7 \pm 7$ & - & - & - & $42 \pm 25$ & - & $85 \pm 56$ \\
\hline
\end{tabular}

The whole Collembola community composition depended on the site $(p<0.01)$, with EF and $\mathrm{RS}_{\mathrm{O}}$ showing the highest dissimilarity, $\mathrm{RS}_{\mathrm{G} 1}$ and $\mathrm{RS}_{\mathrm{C}}$ resulting more similar to each other than the other sites, and Entomobryidae and Onychiuridae/Tullbergiidae as families that occurred together more often (Figure 7). Through multiple comparison between the families always present $\mathrm{RS}_{\mathrm{O}}$ proved to be the site with significantly fewer Entomobryidae than $\mathrm{RS}_{\mathrm{MS}}$ and $\mathrm{RS}_{\mathrm{G}} 3(p<0.01 ; p<0.05)$, and more Hypogastruridae than $\mathrm{RS}_{\mathrm{C}}, \mathrm{RS}_{\mathrm{G} 1}$ and $\mathrm{EF}(p<0.01, p<0.01$, and $p<0.05$ respectively). The Hypogastruridae found in $\mathrm{RS}_{\mathrm{C}}$ were lower than those in $\mathrm{RS}_{\mathrm{G} 3}$, too $(p<0.05)$. Most Isotomidae were in $\mathrm{RS}_{\mathrm{G} 2}$, more than in $\mathrm{RS}_{\mathrm{C}}$ and $\mathrm{EF}(p<0.01)$. The greater presence of Onychiuridae/Tullbergiidae was in $\mathrm{RS}_{\mathrm{G} 3}$, more than $\mathrm{RS}_{\mathrm{G} 2}$ and $\mathrm{EF}(p<0.01)$, whose number was lower than in $\mathrm{RS}_{\mathrm{C}}$ and $\mathrm{RS}_{\mathrm{G} 1}$, too $(p<0.05)$.

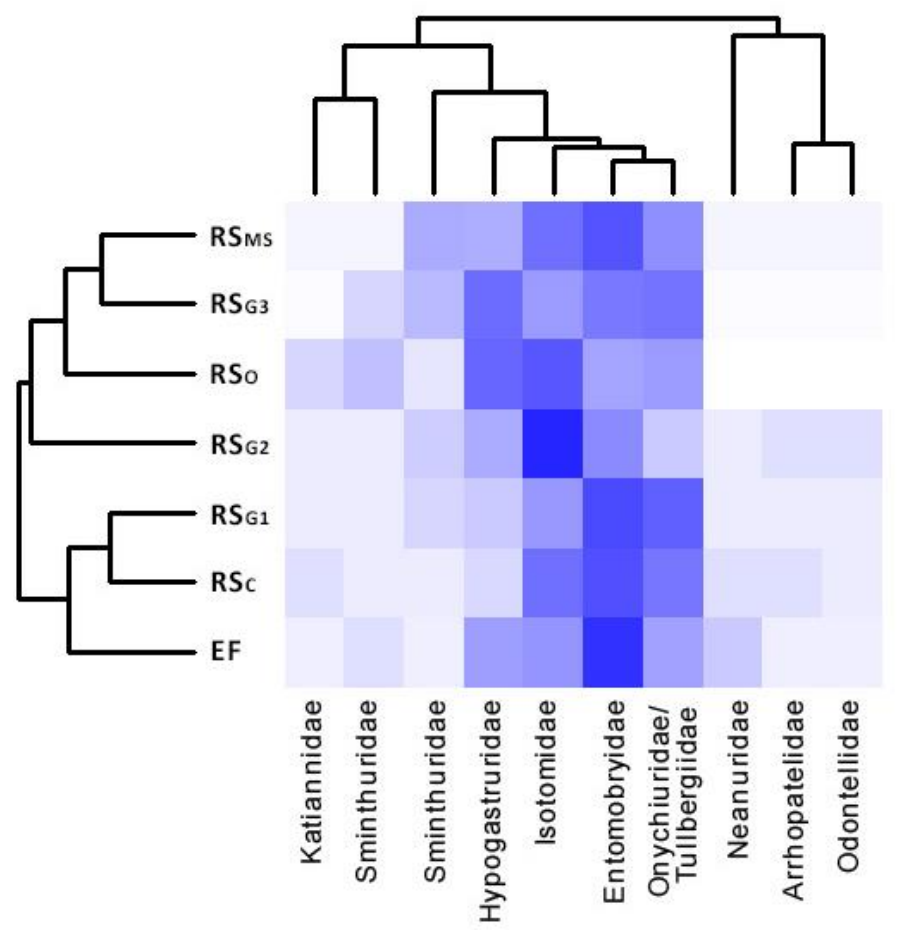

Figure 7. Heat map of the Collembola community composition, with colour intensities proportional to family abundance, and UPGMA (unweighted pair-group method using arithmetic averages) clustering of a matrix of Bray-Curtis distance among sites (on the left side) and of the families that occur more often together (on the top side).

The lowest abundance of Diptera was in the $\mathrm{RS}_{\mathrm{MS}}$, significantly different from $\mathrm{RS}_{\mathrm{G} 1}$ and $\mathrm{RS}_{\mathrm{O}}$ $(p<0.05)$. The only other group found in all sites was Hemiptera, which showed a higher number in $\mathrm{RS}_{\mathrm{G} 3}$ than in $\mathrm{RS}_{\mathrm{C}}$, EF and $\mathrm{RS}_{\mathrm{MS}}(p<0.05)$. Acari/Collembola ratio, being higher in $\mathrm{RS}_{\mathrm{G} 1}$, did not differ significantly between sites. 


\section{Discussion}

In this research, the hydrodynamic characterization of a complex landslide was carried out to evaluate the effects of this system type on soil biodiversity, in terms of soil arthropod community, with the aim to highlight if soil fauna can be a useful tool in landslide studies.

No difference was found in soil $\mathrm{pH}$, similarly to other results obtained from landslide areas by Wilcke [36]. Instead, organic matter content (SOM) varied significantly between sites. As known, soil $\mathrm{pH}$ and SOM alteration can highlight a soil disturbance condition and contribute to altering ecosystem biodiversity.

Not only does SOM influence nutrient availability, it also promotes soil aggregation and improves water infiltration, and its content is known to decline from grassland to cultivated areas [37].

In this study, the lowest amount of SOM was detected in the earth flow area (EF), followed by the main scarp of the rotational slide ( $\mathrm{RS}_{\mathrm{MS}}$ ), and both sites were similar to the cultivated site within the rotational slide $\left(\mathrm{RS}_{\mathrm{C}}\right)$. The differences observed between earth flow $(\mathrm{EF})$ and grasslands $\left(\mathrm{RS}_{\mathrm{G} 1}, \mathrm{RS}_{\mathrm{G} 2}\right.$, $\mathrm{RS}_{\mathrm{G} 3}$ ) show the surface heterogeneity created after slope failure.

It is known that the slip face at the upper edge of a landslide is more unstable, subject to erosion and not readily colonized [38]. Moreover, as suggested by some authors [36], fertility reduction caused by landslides, can involve the whole area. Usually, SOM content is an important feature in driving soil faunal community, and to confirm this, our study shows an evident relationship between SOM content and soil microarthropods. On the other hand, since arthropod faeces are involved in humus production and soil aggregation, soil arthropod abundance and diversity contribute to incrementing soil structure and, consequently, soil stability. In this study, earth flow (EF) showed the poorest soil faunal community, in terms of both number of groups and abundance. Moreover, as for SOM content, soil arthropod abundance in the earth flow $(\mathrm{EF})$ proved to be similar to the main scarp of the rotational slide ( $\left.\mathrm{RS}_{\mathrm{MS}}\right)$ and cultivated area sampled within the rotational slide $\left(\mathrm{RS}_{\mathrm{C}}\right)$. This result confirms that the whole landslide area $(\mathrm{EF}+\mathrm{RS})$ is involved in a soil degradation process. Indeed, the soil arthropod abundance detected in $\mathrm{RS}_{\mathrm{G} 1}$, being similar to $\mathrm{RS}_{\mathrm{C}}$ and lower than a typical grassland condition [39], suggests that a stressful action is affecting the area dramatically. The Collembola community supports this observation since, despite its abundance in the $\mathrm{EF}$ being lower than the other sites, the community structure in this site was similar to $\mathrm{RS}_{\mathrm{G} 1}, \mathrm{RS}_{\mathrm{C}}$ and $\mathrm{RS}_{\mathrm{MS}}(79 \%, 72 \%$ and $69 \%$, respectively). Entomobryidae was the most abundant family found in these sites and the specimens found for this family are almost all epigeic. This result suggests that these specimens were less affected by belowground disturbance as reported in previous studies [40,41]. As known, Collembola have a leading role in the soil structure making; indeed, their faeces contribute to the water-holding capacity and soil aggregation [42]. In this study, the greatest abundance of this group was found in $\mathrm{RS}_{\mathrm{G} 2}$, whose community structure was richer than the other sites, overall for the greatest presence of Isotomidae. $\mathrm{RS}_{\mathrm{G} 3}$ showed a high number of Onychiuridae/Tullbergiidae. As reported by Rusek [43], Onychiuridae, rare in clay soils, are known for their ability to make "microtunnels" in the soil matrix, ability shared with Oribatida Acari, thus increasing aeration and drainage.

As for the Collembola, even for Acari the abundance of this taxon was very low in EF, confirming the degradation condition of this site. Moreover, no difference was detected between Oribatida and others Acari in terms of abundance in this site. On the other hand, $\mathrm{RS}_{\mathrm{G} 3}$, showing the greatest abundance of Oribatida, confirms the importance of a grass cover in soil biodiversity maintenance. Indeed, Oribatida are typical of stable and humid soils, rich in organic matter, since they can survive in submerged condition even over long periods of time, while they are susceptible to drought and their densities decline in man-modified areas subjected to agricultural treatments [44-46]. Centipedes (Chilopoda), which have a thinner cuticle and are sensitive to water stresses [47], were also found in all sites except $\mathrm{EF}$, confirming the degradation condition of this site.

Contributing to SOM contents and consequently to soil resistance to erosion, organisms involved in litter breakdown can play a key role in soil structure maintenance. Coleoptera and Diptera larvae, Symphyla, Diplopoda, Isopoda and Thysanoptera were observed among the main arthropod groups 
found in this study that take part in this process. Abundance of Coleoptera such as Oribatida was greater in $\mathrm{RS}_{\mathrm{O}}$ and in $\mathrm{RS}_{\mathrm{G} 3}$ than in the other sites; both groups can affect soil structure while moving into the pores and pushing particles aside, contributing to soil porosity. Coleoptera larvae, rarely observed in $\mathrm{EF}$, are good indicators of soil water content, as their permeable cuticle makes them susceptible to desiccation [48].

Considering that ants build complicated burrows deep into the ground, forming a network of macropores [49], the greater abundance of this group in $\mathrm{RS}_{\mathrm{G} 2}, \mathrm{RS}_{\mathrm{G} 3}$, and $\mathrm{RS}_{\mathrm{O}}$ when compared to the four other sites, suggests a greater infiltration capacity of these soils. Differently from ants, abundance of Diptera was greater in $\mathrm{RS}_{\mathrm{G} 1}$. Their presence could be related to the occasional presence of goats, factor that produces a high manure content, increasing the abundance of soil dwelling Diptera [50]. This idea is supported by the high number of Symphyla present in this site, whose abundance strongly depends on SOM content [51]. Moreover, Symphyla can give information about soil structure, since they cannot dig tunnels actively in soil and they use existing pores to move in the soil.

Isopoda is a group susceptible to water loss by evapotranspiration and live in moist habitats where they feed mainly on dead and decaying plant material. These considerations highlight that these properties are typical of $\mathrm{RS}_{\mathrm{G} 2}$ and $\mathrm{RS}_{\mathrm{G} 3}$, where this group was observed. Thysanoptera showed similar behaviour, having the greatest abundance in the two sites.

These results point out that soil arthropod community can influence and/or can be influenced by the hydraulic features of a low-permeability system in a landslide area. Firstly, arthropods such as Onychiuridae, Oribatida, Coleoptera, and ants are able to increase both the effective porosity and the permeability of the upper "aquifer" medium, therefore enhancing the effective infiltration of rainwater in a porous low-permeability system. Since these arthropods can increase porosity and permeability in several tens of centimetres below ground, their ability to create macropore ( $\mathrm{mm}$ in dimension) networks causes the vertical permeability to decrease significantly with depth. Due to this vertical heterogeneity, further emphasised by plausible rock weathering, a significant contrast in permeability is expected within the shallow aquifer medium, and temporary perched groundwater could be found within the landslide area during the main rainwater events. Taking into consideration the heterogeneous distributions of the arthropods mentioned above, as well as the geological heterogeneity of the medium studied, temporary perched groundwater could be also discontinuous within the study site. This hypothesis is in agreement with the existence of several temporary springs observed at different altitudes during wintertime (data not shown).

In a wider context, the higher permeability of the shallow "aquifer" system enhances the rapid recharge of the groundwater intercepted and monitored through piezometers A and B, in agreement with the "nervous" hydraulic head fluctuation observed by means of the pressure transducers. The slight difference in time lag between rain event and hydraulic head rise observed between piezometers A and B is also in agreement with the system's heterogeneity.

As for the bioindicator role of some arthropods, Isopoda seem to be a good indicator to detect the areas where the groundwater head comes frequently close to the ground (see examples at $\mathrm{RS}_{\mathrm{G} 2}$ and $\mathrm{RS}_{\mathrm{G} 3}$ ), due to their ability to live in moist habitat. They were actually identified in $\mathrm{RS}_{\mathrm{G} 2}$ and $\mathrm{RS}_{\mathrm{G} 3}$ only, where the groundwater often flows out diffusely, during the main rainwater events. On the whole, these results further emphasize the effectiveness of coupled hydrogeological-biological approaches [52].

\section{Conclusions}

The study suggests that the earth flow, differing from the other sites analysed within the rotational slide for its lower arthropod biodiversity and abundance, appears to be the most stressed area, exposed to erosion, and susceptible to extreme conditions, such as drought. The cultivated area sampled within the rotational slide fits with the many conventional agricultural systems, as reported in other studies, showing low arthropod biodiversity and abundance. The overgrown site instead showed a community composition more similar to $\mathrm{RS}_{\mathrm{G} 3}$, and only partially different from $\mathrm{RS}_{\mathrm{G} 2}$, mainly in total abundance, determined above all by Acari and Collembola densities. These three 
sites are characterized by good conditions in terms of grass presence and consequently rhizosphere, SOM content, water retention and porosity-all of which are important factors in supporting a complex and structured soil arthropod community. $\mathrm{RS}_{\mathrm{G} 1}$ appears to have an intermediate situation, showing great arthropod abundance, mainly due to the high arthropod density strongly related to high SOM contents, yet, on the other hand, showing characteristics observed in disturbed and degraded soils, as the Collembola community suggested, being very similar to those observed in stressed sites.

From the methodological point of view, this study suggests the possibility to effectively merge soil fauna and hydrogeological investigations to better understand the hydraulic features and behaviour of low-permeability systems. At the same time, the approach applied is efficient to distinguish degraded soils, often associated with types of landslides, such as earth flows, that cause partial or complete soil removal, from more preserved soils. The latter are often associated with types of landslide, such as rotational or translational slides, that are characterized by movement in depth, along the sliding surface, while the upper portion of the depleted mass can remain untouched.

The use of the soil fauna as indicator of the health state of the soil in landslide areas may contribute to the evaluation of the potentiality of these surfaces for agricultural purposes. For instance, plants (like maize) or trees (like apple orchards) that need a consistent rate of water would represent kind of cultivation that could be irrigated by extracting the waters from the landslides themselves once the paths of these have been identified within the body of the landslide.

The surfaces of landslides, which are obviously not active or characterized by very slow rate of movement like in the case studied, may represent for some portions within mountain chains, such as the Italian Apennines, the only areas suitable for cultivation. In the Apennines, this fact occurred in the past when many large landslides were exploited with these purposes, and for settlements, but even today they could represent the way to restoration and re-use of these surfaces, contributing to the maintenance and care of the territory and the prevention of landslide movement.

Author Contributions: Conceptualization was developed by A.C., C.M., E.P., F.C.; methodology was carried out by A.C., C.M., E.P., F.C., S.R.; software development of the geological aspects was conducted by R.F.; formal analysis with statistical application was made by S.R.; data collection and investigation process were carried out by A.C., C.M., E.P., S.R.; C.L.F. helped in chemical analysis and F.D.C. in Collembola families identification; data curation was managed by A.C., E.P., R.F., S.R.; writing of the original draft preparation and review and editing were realized by A.C., C.M., E.P., F.C., S.R.; supervision was fulfilled by C.M. and F.C.; project administration and funding acquisition were achieved by A.C.

Funding: This research was funded by Agency of Civil Protection-Emilia Romagna Region Administration, and by Parma University grant number [CHELLFIL12; FILCHELLI14 - Head: A. Chelli] and The APC was funded by grant number [MENTA_2018_CT_MILAZZO_RAM - Head: C. Menta].

Acknowledgments: Work supported by the National Institute of Oceanography and Experimental Geophysics.

Conflicts of Interest: The authors declare no conflict of interest.

\section{References}

1. Boccaletti, M.; Elter, P.; Guazzone, G. Plate Tectonic Models for the Development of the Western Alps and Northern Apennines. Nat. Phys. Sci. 1971, 234, 108-111. [CrossRef]

2. Kligfield, R. The northern Apennines as a collisional orogen. Am. J. Sci. 1979, 279, 676-691. [CrossRef]

3. Vai, G.B.; Martini, P. Anatomy of an Orogen: The Apennines and Adjacent Mediterranean Basins; Kluwer Academic Publishers: Tranbjerg, Denmark, 2001; ISBN 9780412750403.

4. Molli, G. Northern Apennine-Corsica orogenic system: An updated overview. Geol. Soc. Lond. Spec. Publ. 2008, 298, 413-442. [CrossRef]

5. Crozier, M.J. Landslide geomorphology: An argument for recognition, with examples from New Zealand. Geomorphology 2010, 120, 3-15. [CrossRef]

6. Carlini, M.; Chelli, A.; Vescovi, P.; Artoni, A.; Clemenzi, L.; Tellini, C.; Torelli, L. Tectonic control on the development and distribution of large landslides in the Northern Apennines (Italy). Geomorphology 2016, 253, 425-437. [CrossRef] 
7. Perrone, A.; Iannuzzi, A.; Lapenna, V.; Lorenzo, P.; Piscitelli, S.; Rizzo, E.; Sdao, F. High resolution electrical imaging of the Varco d'Izzo earthflow (southern Italy). J. Appl. Geophys. 2004, 56, 17-29. [CrossRef]

8. Bertolini, G.; Corsini, A.; Tellini, C. Fingerprints of Large-Scale Landslides in the Landscape of the Emilia Apennines. In Landscapes and Landforms of Italy; Soldati, M., Marchetti, M., Eds.; Springer International Publishing: Berlin, Germany, 2017; pp. 215-224. [CrossRef]

9. Carlini, M.; Chelli, A.; Francese, R.; Giacomelli, S.; Giorgi, M.; Quagliarini, A.; Carpena, A.; Tellini, C. Landslides types controlled by tectonics-induced evolution of valley slopes (Northern Apennines, Italy). Landslides 2018, 15, 283-296. [CrossRef]

10. Antolini, G.; Pavan, V.; Tomozeiu, R.M.V. Atlante Climatico dell'Emilia-Romagna 1961-2015; ARPAe: Bologna, Italy, 2017; ISBN 9788887854442.

11. Jongman, B.; Hochrainer-Stigler, S.; Feyen, L.; Aerts, J.C.J.H.; Mechler, R.; Botzen, W.J.W.; Bouwer, L.M.; Pflug, G.; Rojas, R.; Ward, P.J. Increasing stress on disaster-risk finance due to large floods. Nat. Clim. Chang. 2014, 4, 264-268. [CrossRef]

12. Palis, E.; Lebourg, T.; Vidal, M.; Levy, C.; Tric, E.; Hernandez, M. Multiyear time-lapse ERT to study short- and long-term landslide hydrological dynamics. Landslides 2017, 14, 1333-1343. [CrossRef]

13. Bièvre, G.; Jongmans, D.; Goutaland, D.; Pathier, E.; Zumbo, V. Geophysical characterization of the lithological control on the kinematic pattern in a large clayey landslide (Avignonet, French Alps). Landslides 2016, 13, 423-436. [CrossRef]

14. Segoni, S.; Piciullo, L.; Gariano, S.L. A review of the recent literature on rainfall thresholds for landslide occurrence. Landslides 2018, 15, 1483-1501. [CrossRef]

15. Lissak, C.; Maquaire, O.; Malet, J.P.; Bitri, A.; Samyn, K.; Grandjean, G.; Bourdeau, C.; Reiffsteck, P.; Davidson, R. Airborne and ground-based data sources for characterizing the morphostructure of a coastal landslide. Geomorphology 2014, 217, 140-151. [CrossRef]

16. Geertsema, M.; Pojar, J.J. Influence of landslides on biophysical diversity-A perspective from British Columbia. Geomorphology 2007, 89, 55-69. [CrossRef]

17. Geertsema, M.; Highland, L.; Vaugeouis, L. Environmental Impact of Landslides. In Landslides—Disaster Risk Reduction; Springer: Berlin/Heidelberg, Germany, 2009; pp. 589-607, ISBN 9783540699705. [CrossRef]

18. Pimentel, D. Soil erosion: A food and environmental threat. Environ. Dev. Sustain. 2006, 8, 119-137. [CrossRef]

19. Wardle, D.A.; Bardgett, R.D.; Klironomos, J.N.; Setälä, H.; van der Putten, W.H.; Wall, D.H. Ecological linkages between aboveground and belowground biota. Science 2004, 304, 1629-1633. [CrossRef]

20. Smith, R.B.; Commandeur, P.R.; Ryan, M.W. Soils, Vegetation, and Forest Growth on Landslides and Surrounding Logged and Old-Growth Areas on the Queen Charlotte Islands; BC Land Management Report; Ministry of Forests: Victoria, BC, Canada, 1986; Volume 41, p. 95.

21. Vescovi, P. Note Illustrative Della Carta Geologica D'italia Alla Scala 1:50.000. Foglio 216 Borgo Val di Taro; Servizio Geologico d'Italia-Regione Emilia Romagna: Roma, Italy, 2002; p. 115.

22. Cruden, D.M.; Varnes, D.J. Landslide Types and Processes, Special Report. In Landslides: Investigation and Mitigation; Turner, A.K., Shuster, R.L., Eds.; National Academy Press: Washington, DC, USA, 1996; Volume 247, pp. 36-75.

23. Cartografia Interattiva e Banche Dati. Available online: Ambiente.regione.emilia-romagna.it/it/geologia/ cartografia/webgis-banchedati (accessed on 5 August 2019).

24. Morin, R.H.; Carleton, G.B.; Poirier, S. Fractured-aquifer hydrogeology from geophysical logs; the passaic formation, New Jersey. Ground Water 1997, 35, 328-338. [CrossRef]

25. Cook, P.G.; Love, A.J.; Dighton, J.C. Inferring ground water flow in fractured rock from dissolved radon. Ground Water 1999, 37, 606-610. [CrossRef]

26. Petrella, E.; Naclerio, G.; Falasca, A.; Bucci, A.; Capuano, P.; De Felice, V.; Celico, F. Non permanent shallow halocline in a fractured carbonate aquifer, southern Italy. J. Hydrol. 2009, 373, 267-272. [CrossRef]

27. Aquino, D.; Petrella, E.; Florio, M.; Celico, P.; Celico, F. Complex hydraulic interactions between compartmentalized carbonate aquifers and heterogeneous siliciclastic successions: A case study in southern Italy. Hydrol. Process. 2015, 29, 4252-4263. [CrossRef]

28. FAO. Guidelines for Profile Description, 3rd ed.; Soil Resources, Management and Conservation Service, Land and Water Development Division; FAO: Rome, Italy, 1990. 
29. Jackson, M.L. Soil Chemical Analysis; Prentice Hall, Inc.: Englewood Cliffs, NJ, USA, 1958; 498 S. DM 39.40. Zeitschrift für Pflanzenernährung Düngung Bodenkd. 2007, 85, 251-252. [CrossRef]

30. Ball, D.F. Loss-On-Ignition As An Estimate Of Organic Matter And Organic Carbon In N -Calcareous Soils. J. Soil Sci. 1964, 15, 84-92. [CrossRef]

31. The Taxonomicon. Available online: http://taxonomicon.taxonomy.nl/ (accessed on 5 August 2019).

32. Bachelier, P.G. La vie Animale Dans les sols I. -Déterminisme de la Faune des Sols; ORSTOM: Paris, France, 1963.

33. Borcard, D.; Gillet, F.; Legendre, P.; Borcard, D.; Gillet, F.; Legendre, P. Association Measures and Matrices. In Numerical Ecology with R; Springer: New York, NY, USA, 2011; pp. 31-51, ISBN 978-1-4419-7975-9. [CrossRef]

34. R Core Team. R: A Language and Environment for Statistical Computing; R Foundation for Statistical Computing: Vienna, Austria, 2018; Available online: https://www.R-project.org/ (accessed on 23 February 2019).

35. Petrella, E.; Celico, F. Mixing of water in a carbonate aquifer, southern Italy, analysed through stable isotope investigations. Int. J. Speleol. 2013, 42, 25-33. [CrossRef]

36. Wilcke, W.; Valladarez, H.; Stoyan, R.; Yasin, S.; Valarezo, C.; Zech, W. Soil properties on a chronosequence of landslides in montane rain forest, Ecuador. CATENA 2003, 53, 79-95. [CrossRef]

37. Chibsa, T.; Ta, A.A. Assessment of Soil Organic Matter under Four Land Use Systems in the Major Soils of Bale Highlands, South East Ethiopia b. Factors Affecting Soil Organic Matter Distribution. World Appl. Sci. J. 2009, 6, 1506-1512.

38. Walker, L.R.; Velázquez, E.; Shiels, A.B. Applying lessons from ecological succession to the restoration of landslides. Plant Soil 2009, 324, 157-168. [CrossRef]

39. Menta, C.; Leoni, A.; Gardi, C.; Conti, F. Are grasslands important habitats for soil microarthropod conservation? Biodivers. Conserv. 2011, 20, 1073-1087. [CrossRef]

40. Parisi, V.; Menta, C.; Gardi, C.; Jacomini, C.; Mozzanica, E. Microarthropod Communities as a Tool to Assess Soil Quality and Biodiversity: A new Approach in Italy. Agric. Ecosyst. Environ. 2005, 105, 323-333. [CrossRef]

41. Parisi, V.; Menta, C. Microarthropods of the soil: Convergence phenomena and evaluation of soil quality using QBS-ar and QBS-c. Fresenius Environ. Bull. 2008, 17, 1170-1174.

42. Van Vliet, P.C.J.; Hendrix, P.F. Role of fauna in soil physical processes. In Soil Biological Fertility: A Key to Sustainable Land Use in Agriculture; Springer: Dordrecht, The Netherlands, 2007; pp. 61-80, ISBN 9781402066184. [CrossRef]

43. Rusek, J. Soil microstructures-contributions on specific soil organisms. Quest. Entomol. 1985, 21, 497-514.

44. Schatz, H.; Behan-Pelletier, V. Global diversity of oribatids (Oribatida: Acari: Arachnida). Hydrobiologia 2008, 595, 323-328. [CrossRef]

45. Maraun, M.; Scheu, S. The Structure of Oribatid Mite Communities (Acari, Oribatida): Patterns, Mechanisms and Implications for Future Research. Ecography 2000, 23, 374-383. [CrossRef]

46. Gergocs, V.; Hufnagel, L. Application of Oribatid Mites as Indicators (Review). Appl. Ecol. Environ. Res. 2009, 7, 79-98. [CrossRef]

47. Lavelle, P. (Patrick); Spain, A.V. Soil organisms. In Soil ecology; Springer Science \& Business Media, Ed.; Springer: Dordrecht, The Netherlands, 2007; p. 654, ISBN 9780306481628.

48. Brown, V.K.; Gange, A.C. Insect Herbivory Insect Below Ground. Adv. Ecol. Res. 1990, 20, 1-58.

49. Gabet, E.J.; Reichman, O.J.; Seabloom, E.W. The effects of bioturbation on soil processes and sediment transport. Annu. Rev. Earth Planet. Sci. 2003, 31, 249-273. [CrossRef]

50. Frouz, J. Use of soil dwelling Diptera (Insecta, Diptera) as bioindicators: A review of ecological requirements and response to disturbance. Agric. Ecosyst. Environ. 1999, 74, 167-186. [CrossRef]

51. Edwards, C.A. The ecology of Symphyla. Entomol. Exp. Appl. 1958, 1, 308-319. [CrossRef]

52. Petrella, E.; Bucci, A.; Ogata, K.; Zanini, A.; Naclerio, G.; Chelli, A.; Francese, R.; Boschetti, T.; Pittalis, D.; Celico, F. Hydrodynamics in Evaporate-Bearing Fine-Grained Successions Investigated through an Interdisciplinary Approach: A Test Study in Southern Italy-Hydrogeological Behaviour of Heterogeneous Low-Permeability Media. Geofluids 2018, 2018. [CrossRef]

(C) 2019 by the authors. Licensee MDPI, Basel, Switzerland. This article is an open access article distributed under the terms and conditions of the Creative Commons Attribution (CC BY) license (http://creativecommons.org/licenses/by/4.0/). 